\title{
Incrementalism, Normalisation, Partnership and Reassurance: PRC's Quest for Success in the 1990s
}

\author{
Muhammad Shoaib, ${ }^{*}$ Ahmad Sabat ${ }^{* *} \mathcal{E}$ Dr Saira Aquil ${ }^{* * *}$
}

\begin{abstract}
The People's Republic of China's effort to rehabilitate its post-6/4 image and overcome international isolation was not without challenges. Internal problems, regime insecurity, failing socialism, and the fear of anarchy dominated the context in which leadership of the Communist Party of China took decisions. Lack of consensus on the policy towards major powers and institutional rifts complicated the decision-making process. Against this backdrop, Jiang Zemin's astute approach enabled the Republic to recover from the 1989 and 1996 setbacks, assuage vulnerabilities, and overcome challenges to its ascent. Its external policy - encompassing incrementalism, normalisation, partnership and reassurance helped the leadership defend itself and maintain regional stability. Beijing resolved frontier disputes with neighbours, improved relations with the developed world, opened up its economy, and maintained peaceful, working relations with the
\end{abstract}

\footnotetext{
* The author teaches at COMSATS University, Vehari, Pakistan. He is a doctoral candidate at the Area Study Center for Africa, North \& South America, Quaid-i-Azam University, Pakistan. He can be contacted at: shoaibm37@yahoo.com.

** The author is Lecturer at COMSATS University, Vehari Campus, Pakistan. He has been Visiting Fellow at the Department of Political Science, Columbia University, USA. He can be contacted at: ahmadsabat@ciitvehari.edu.pk.

***: The author is Assistant Professor at the Department of Defense and Strategic Studies, Quaid-i-Azam University, Pakistan. She can be contacted at: saquil@qau.edu.pk.
}

@ 2019 by the Islamabad Policy Research Institute.

IPRI Journal $\square$ XIX (2): 96-119.

https://doi.org/10.31945/iprij.190204. 
Incrementalism, Normalisation, Partnership and Reassurance:

PRC's Quest for Success in the 1990s

United States. The country became part of multilateral regional and global institutions that reflected its interest in working within the global order in the years to come. The decade of prudent, low-profile approach prepared the PRC for a greater, effective role in the Twenty-first Century.

Keywords: Regime Insecurity, Leadership, Communist Party, External Policy.

\section{Introduction}

T ${ }^{i}$ Jinping's People's Republic of China represents four decades of economic growth and prudent foreign policy. Its difference, from that of Mao Zedong, is evident in most aspects. ${ }^{1}$ A feature common between the Mao and $\mathrm{Xi}$ regimes, however, is active foreign policy. Like Mao, Xi has so far placed great importance on foreign policy, and has shown willingness to use various tools to achieve his objectives on the regional and global stage. Xi's China has indeed gone global - it has constructed and leased a base in Djibouti and its nuclear-powered submarines have access to ports in South Asia, Africa, and the Middle East. ${ }^{2}$ His trademark Belt and Road Initiative (BRI) has the potential to define the future of global growth. However, while Xi's external policy may have partly comprised of some continuities, but, primarily, it (as well as his ruling style) ${ }^{3}$ is different from Deng Xiaoping's dictum - avoid the

${ }^{1}$ Chen Jian, Mao's China and the Cold War (Chapel Hill: The University of North Carolina Press, 2001).

2 David Brewster, "China's Limited Role in the Indian Ocean," Real Clear Defense, February 12, 2019.

${ }^{3}$ Deng's successors, especially Hu Jintao, strove for consensus. In fact, collective leadership with consensus was to replace the trend of arbitrary decisions by supreme leaders. David Lampton, Following the Leader: Ruling China, from Deng Xiaoping to Xi Jinping (Berkeley: University of California Press, 2014); Former US Deputy Assistant Secretary of State Susan Shirk calls it "personalistic" rule. Susan Shirk, "China in Xi's New Era: The Return to Personalistic Rule," Journal of Democracy 29, no. 2 (2018): 22-36. doi: 10.1353/jod.2018.0022. 


\section{Muhammad Shoaib, Ahmad Sabat \& Dr Saira Aquil}

limelight, never take the lead, and try to accomplish something - that helped China become a global power. ${ }^{4}$

Deng's emphasis on low-profile foreign policy and the 'virtue of dullness' that distinguished his handpicked successors in the 1990s enabled China to benefit from the so-called window of strategic opportunity. The Chinese Communist Party (CCP) leadership focused on continuing Deng's 'four modernisation' (emphasising agriculture, industry, technology, and defense), four cardinal principles, and antispiritual pollution campaign (also referred to as 'cleansing spiritual pollution'). ${ }^{5}$ The drive of 'opening China economically' also continued. The country, in the 1990s, largely avoided getting entangled in geopolitical disputes involving neighbours; and initiating limited conflicts on northern and southern borders. ${ }^{6}$ Its external policy, simply put, was responsive. It was this period that shaped China's future: the foreign policy of 1990s enabled the PRC to emerge as a global power in the Twenty-first Century.

The responsiveness of Chinese policy was evident in multiple domains. Initiatives were taken mostly to respond to threats emanating from an array of sources, mostly internal. Most policy actions, ranging from notable border agreements to the Taiwan Strait crisis to the creation

4 Ezra Vogel, Deng Xiaoping and the Transformation of China (Cambridge: Harvard University Press, 2011), 714; Son Daekwon, "Xi Jinping Thought vs. Deng Xiaoping Theory," The Diplomat, October 25, 2017, https://thediplomat.com/2017/10/xi-jinpingthought-vs-deng-xiaoping-theory/; Steve Tsang, "What is Xi Jinping Thought?," Project Syndicate, February 5, 2019, https://www.project-syndicate.org/commentary/china-xijinping-thought-reform-by-steve-tsang-2019-02?barrier=accesspaylog.

5 Four cardinal principles included upholding the socialist road, dictatorship of the proletariat, leadership of $\mathrm{CCP}$, and Marxism-Leninism-Mao Zedong Thought. $\mathrm{Bao} \mathrm{Pu}$, Renee Chiang, and Adi Ignatius, ed. and trans., Prisoner of the State: The Secret Journal of Premier Zhao Ziyang (New York: Simon and Schuster, 2009).

${ }^{6}$ Entangling mainly refers to Korean and Vietnam wars. Limited conflict - like with India, USSR, and Vietnam during the Cold War - were avoided. China's defense budget grew in accordance with the overall economic growth. David Shambaugh, Modernizing China's Military: Progress, Problems, and Prospects (Berkeley: University of California Press, 2002), 184-283. For economic growth, see, Wayne Morrison, China's Economic Rise: History, Trends, Challenges, and Implications for the United States, report (CRS Report no. RL33534, Washington, D.C.: Congressional Research Service, 2018). 
Incrementalism, Normalisation, Partnership and Reassurance:

PRC's Quest for Success in the 1990s

of Shanghai Five (that later became Shanghai Cooperation OrganizationSCO), either responded to developments in the region or sought to assuage vulnerabilities. Military modernisation programmes followed the same logic - new weapon programmes emphasised the defensive aspect of technology - and growth in the defense budget merely reflected economic growth. Economic initiatives, though moderate in scope as compared to that of today's China, were prominent. Beijing's focus remained on economic development, regional integration, and participation in global trade regimes.

An important factor underpinning Beijing's external policy - apart from Deng's influence and the end of the Cold War was regime insecurity (and the fear of anarchy) that affected its capacity. ${ }^{7}$ That insecurity is reflected in the context in which the CCP leadership took decisions. Without this context, it may be difficult to understand why China pursued its low-profile foreign policy in early post-Cold War years. Why did China limit its response to regional and global developments? And why did China speed up participation in the United States (US)-led global [political and economic] order?

\section{Sources, Sequence and Pattern}

The study of PRC politics is challenging. Unlike the US, China does not declassify documents in a systematic way. The declassification drive in China, circa 2006, was reversed by the government and access to available archives was curtailed. ${ }^{8}$ Yet, most of the documents available with research centres mainly cover the Cold War. Since this article focuses on the post-Cold War years, it quotes literature produced in the West by

\footnotetext{
${ }^{7}$ Sulmaan Wasif Khan, Haunted by Chaos: China's Grand Strategy from Mao Zedong to Xi Jinping (Cambridge: Harvard University Press, 2018).

8 Patrick Boehler, "China's Foreign Ministry Curtails Access to Declassified Historic Archives," South China Morning Post, August 9, 2013, https://www.scmp.com/news/china-insider/article/1295456/chinas-diplomats-curtailaccess-their-historic-archives.
} 
academics, journalists, and analysts specialising on the PRC. ${ }^{9}$ A similar caution is also important in the sequencing of events and tracing their sources. For example, while retired party elders, especially Deng, played a decisive role in the early 1990s, their influence with age, fluctuated. Lastly, the PRC diplomacy has a style of its own. Threat-and-talk or fightand-talk patterns were not uncommon for Chinese negotiators. Because of its size and location, the PRC's recent diplomatic history is replete with parallel, concurrent pursuits.

This study focuses on the PRC's external policy, in the context of regime insecurity and pressure. It briefly discusses the backdrop and divides the PRC's pursuits on the external front into five sections. Beginning from the $6 / 4$ context, it discusses Beijing's diplomacy of damage control, agreements on frontier disputes, response to the US hegemony, the course of action in Taiwan Strait crisis, and post-crisis diplomacy. The beginning and end of this article are embedded in the present. The rest focuses on the 1990s since the objective is to highlight the importance of PRC's external policy (in 1990s) as underpinning its ascent as a global power.

\section{Insecurity, Vulnerability and Pressure}

China faced several challenges in the early 1990s. Together they were enough to threaten the existence of CCP and the PRC - the state that the CCP ruled. A generic tendency affecting analysis on China in the late 1980s and early 1990s is the emphasis on problems at the external front. Failure of socialism in Eastern Europe and the end of the Cold War (along with a weakened Union of Soviet Socialist Republics (USSR) are a few prominent external challenges. Analysing China's external policy in the context of failing socialism and the so-called 'End of History' is useful, but, as available sources suggest, challenges on the internal front are crucial for understanding China of the 1990s.

\footnotetext{
9 The featured collection of Chinese archives at Wilson Centre primarily covers the Cold War. "Chinese Foreign Policy Database", Wilson Centre Digital Archive, https://digitalarchive.wilsoncenter.org/theme/chinese-foreign-policy-database.
} 
Incrementalism, Normalisation, Partnership and Reassurance:

PRC's Quest for Success in the 1990s

A notable threat facing the CCP on internal front in the late 1980s was the challenge to the ruling style and demand for 'actual rights'. University professors including Fang Lizhi inspired students to come out and express their dissatisfaction. ${ }^{10} \mathrm{~A}$ negotiated settlement between the authorities and demonstrators temporarily brought an end to the student demonstrations. However, this solution proved tentative. Only two years after the first wave of demonstrations, students and liberals, aspiring for political reforms, were again on the roads - Tiananmen Square in particular. Hu Yaobang's death provided them with an opportunity to assemble. ${ }^{11}$ As days went by, their numbers grew; many thought that their growing numbers would pressure the authorities to acquiesce.

Tiananmen Square demonstrations troubled the CCP - causing disagreement within the senior leadership. The Party was divided on the response - disagreements made the pre-existing rifts public. ${ }^{12}$ A group led by Hu's successor Zhao Ziyang opposed the use of force and advocated against bringing in the Army to crush protests. ${ }^{13}$ Ziyang, however, lost the battle against the party elders and conservatives - he resigned from the post of CCP General Secretary. To avoid leadership crisis, Deng effectively took control (even if he was now very old to continue his role): his protégés followed his decision to bring in the Army. ${ }^{14}$ The Tiananmen 'massacre $(6 / 4)$ ', as the Western media labelled

${ }^{10}$ Intellectuals leading the movement demanded political reforms from the government to provide freedom of speech and press. John Garver, China's Quest: The History of the Foreign Relations of the People's Republic (New York: Oxford University Press, 2016), 459-60.

${ }^{11}$ Khan, Haunted by Chaos, 165-166.

${ }^{12}$ Premier Li Peng and Vice-Premier Yao Yilin had the support of two party elders: Chen Yun and Li Xiannian (Xiannian served as Hua Guofeng's Principal Economic Advisor). Zhao generally followed Yaobang's line in economic matters. He was supported by $\mathrm{Hu}$ Qili on his stand against the infamous April 26 People's Daily editorial. Pu, et al., Prisoner of the State.

${ }^{13}$ Ibid. xv, 29; Rowena Xiaoqing He, "The 1989 Tiananmen Movement and its Aftermath," Asian History, Oxford Research Encyclopedias, December 2017, doi: 10.1093/acrefore/9780190277727.013.157.

${ }^{14}$ The students' objectives were political and economic reforms, constitutional freedoms, press laws, privately run press, and fighting against corruption. Andrew Nathan, "The Tiananmen Papers," Foreign Affairs, January 1, 2001, https://www.foreignaffairs.com/articles/asia/2001-01-01/tiananmen-papers. 
Muhammad Shoaib, Ahmad Sabat \& Dr Saira Aquil

it, brought severe criticism from the US and European Union (EU) states. President George Bush's administration in Washington put Beijing under sanctions; ${ }^{15}$ and many governments in Europe followed the move.

\section{China's Post-6/4 Diplomacy of Damage Control}

China's priority in 1989 and early 1990s was to control the damage the events of $6 / 4$ had caused. Its external policy focused on small, incremental steps aimed at repairing the damage to the country's image and assuaging its international isolation. The backlash of military clampdown on June 4 was severe as discussed earlier - most of the developed world quickly put China under economic and military sanctions. The CCP leadership had to be circumspect since popular opinion was against its rule. The US government had already announced a temporary suspension of arms sales. Also, it had suspended military exchanges and waived visa requirements for Chinese students studying in the US. The Bush administration had announced that it would oppose new loans to China by multilateral institutions. Japan, second only to the US in 1989 , had changed the status of Chinese exports and suspended aid and new loans. ${ }^{16}$

The PRC leadership, especially Premier Li Peng, had become a target of 'popular opinion'. A handful of foreign observers considered him to be the man who set the 6/4 crisis in motion; expectedly, many states were reluctant to host him. It was evident that the CCP leadership, primarily Deng Xiaoping, had misunderstood the magnitude of reaction: Deng probably expected that the [limited] negative reaction would last only a few months. ${ }^{17}$ Adding to Beijing's worries were possible implications of 6/4 in terms of reversion of Hong Kong (followed by Macao). Against this backdrop, Foreign Minister Qian Qichen emerged as Beijing's man. China's Ministry of Foreign Affairs (MFA), under his

\footnotetext{
${ }^{15}$ On US-China relations after 6/4, see, Steve Chan, review of Same Bed, Different Dreams: Managing U.S.-China Relations, 1989-2000, by David Lampton, Journal of East Asian Studies, March 24, 2016, doi: https://doi.org/10.1017/S1598240800001387, 21-30; Robert Sutter, U.S.-Chinese Relations: Perilous Past, Pragmatic Present (Lanham: Rowman \& Littlefield, 2010), 95-114.

${ }^{16}$ Garver, China's Quest, 485-504.

${ }^{17}$ Sutter, U.S.-Chinese Relations, 95.
} 
Incrementalism, Normalisation, Partnership and Reassurance:

PRC's Quest for Success in the 1990s

guidance, pursued a low-key, low-profile but hard bargaining [foreign policy] strategy. ${ }^{18}$ Three years of continuous struggle and an incremental approach, from the developing to developed states, helped China achieve its objective - rehabilitation of the country's image.

The 'damage control strategy' from 1989 to 1992, underscored two approaches: incrementalism and normalisation. The PRC MFA arranged an array of activities. The MFA efforts started from friendly socialist and developing countries. ${ }^{19}$ Almost immediately after 6/4, Qian toured Africa (July 1989). He visited Botswana, Zimbabwe, Angola, Zambia, Mozambique, and Lesotho. Deputy Foreign Minister Yang Fuchang paid visits to Senegal, Ivory Coast, Gambia, Sierra Leone, and Ghana. Wan Li visited Islamabad in May 1990. Li Peng, the public face of 6/4, visited ten states in November-December 1989; in April 1990, he visited nine states of South and Southeast Asia. General Secretary Jiang Zemin visited Democratic People's Republic of Korea (DPRK) in March 1990. President Yang Shangkun's visits covered Mexico, Brazil, Uruguay, Argentina, and Chile in May. In late 1990, Qian visited Egypt, the United Arab Emirates, Sudan, Iraq, Syria, Saudi Arabia, and Jordon.

In January 1991, Qian was back in Africa to visit Ethiopia, Uganda, Kenya, and Tanzania. Following the visits of African states, he visited Portugal, Spain, Poland, Bulgaria, Greece, and Malta - it was the first European visit of a Chinese leader. Li paid an important visit to India in December 1991 - the first ever by a Chinese Premier in 31 years. ${ }^{20}$ The most important of Li's visits materialised in 1991 when he toured Europe — to visit Italy, Switzerland, Portugal, Spain — and the US. He visited the US to attend a United Nations (UN) session (he was given a 20-minute private meeting with President Bush amid public outrage and protests. $)^{21}$

\footnotetext{
${ }^{18}$ Sutter, U.S.-Chinese Relations.

${ }^{19}$ Third world countries and socialist states were expected to warmly welcome the PRC leadership. Their support was important for opposing a possible US move to punish the country in the UN on its human rights record.

${ }^{20}$ This visit was of limited utility in terms of frontier disputes, but it reduced pressure on the PRC. For details of visits, see Sutter, U.S.-Chinese Relations.

${ }^{21}$ Seth Faison Jr., "Summit at the UN: Bush and Chinese Prime Minister Meet Briefly at U.N. amid Protests," New York Times, February 1, 1992,
} 
By early 1992, it was evident that Beijing's incremental [diplomatic] approach was succeeding.

The second half of the 'damage control strategy', normalisation, emphasised long-estranged states in Asia, such as Indonesia. This normalisation process started from the Republic of Korea with which China had maintained unofficial relations since the mid-1980s. In April 1991, Vice Foreign Minister Liu Huaqiu visited Seoul for a UN meeting; Qian and Li Lanqing visited Seoul to attend an Asia-Pacific Economic Cooperation (APEC) conference in September. Enhanced interaction and mutual willingness enabled both sides to normalise relations in August $1992 .{ }^{22}$ China also moved to normalise bilateral relations with Indonesia that were broken in 1967 (Qian's February 1989 meeting with President Suharto in Japan had already paved the way for normalisation). After $6 / 4$, however, China precipitated the process. Indonesian Foreign Minister was invited for a visit in July 1990 that led to resumption of diplomatic relations. Singapore followed suit two months later. Lee Kuan Yew visited Beijing in October 1990, following Premier Li’s August 1990 visit, to lead initiation of diplomatic relations. ${ }^{23}$

The PRC incrementalism (along with normalisation) was a success. The leadership knew that the road to the developed world passed through Japan. And they rightly understood that Tokyo was a 'weak link' in the united front. Tokyo's desire to be a bridge was, thus, well-received in Beijing. China encouraged Japan to play an active role in bringing it closer to the West. Several Chinese leaders visited Japan in the early 1990s; noteworthy among them were visits by Zou Jiahua from State Planning Commission and State Councilor Li Tieying. China also responded positively to some of Tokyo's concerns. Martial law in Beijing was lifted in January 1990. Relations with Japan ultimately paid off.

\footnotetext{
https://www.nytimes.com/1992/02/01/world/summit-un-bush-chinese-prime-ministermeet-briefly-un-amid-protests.html.

${ }^{22}$ Relations with the Republic of Korea implied a PRC hedge against Japan's growing power and [possible] US-led peaceful evolution in China. Robert Sutter, Chinese Foreign Relations: Power and Policy since the Cold War (Lanham: Rowman \& Littlefield, 2012), 194.
}

${ }^{23}$ Ibid. 
Incrementalism, Normalisation, Partnership and Reassurance:

PRC's Quest for Success in the 1990s

Japanese Prime Minister Toshiki Kaifu became the first leader (from the industrialised democracies) to visit Beijing after 6/4. In 1992, Emperor Akihito visited Beijing — the first of imperial visits in the PRC's history. ${ }^{24}$

Japan emerged as China's gateway to West European countries, for many European states looked at Tokyo positively. In 1990, the EU agreed to cancel sanctions (mainly economic) and normalise relations with Beijing. Britain took the lead in the EU partly because of the upcoming Hong Kong reversion. British Prime Minister John Major became the first EU leader to visit Beijing in September 1991. Not only was Major's visit important for Hong Kong, but it also implied that major US allies intended to normalise ties with China. ${ }^{25}$ As for relations with the US, Deng led the decision-making, for he understood the US' importance and influence. Although he declined to attend Bush's call after the US announcement of arms sales to Taiwan, he showed sufficient understanding and flexibility for Bush's position before 1992 elections.

Deng displayed cool-headedness and emphasised the continuity of 'four modernisations' - it was important to keep the larger picture in mind. China showed pliability. It agreed to work with the US on several matters, ranging from Fang Lizhi to political detainees to the use of force against Iraq. It effectively used upheaval in the Middle East to mend relations with the US. Qian and his American counterpart James Baker bargained on the lifting of sanctions for approval of use of force against Iraq in the UN Security Council (UNSC). Their implicit agreement showed that China was no longer a pariah. Its 'damage control' was succeeding.

\section{Territorial Agreements, Normalisation and Improvement}

Challenges to survival and subsequent diplomacy of damage control opened avenues for PRC to initiate, normalise, and improve relations in its

${ }^{24}$ Sutter, Chinese Foreign Relations, 179-180.

${ }^{25}$ David Holley, "British Leader Visits Beijing, Easing Sanctions," Los Angeles Times, September 3, 1991, https://www.latimes.com/archives/la-xpm-1991-09-03-mn-2070story.html. 
periphery. This required settlement of frontier disputes to reduce trigger points. Fravel argues that regime insecurity created a strong incentive for PRC to demarcate boundaries with socialist neighbours - Soviet Union, Vietnam, and Laos - and newly emerged Central Asian Republics (CARs) to resolve the few remaining frontier disputes. ${ }^{26}$

China signed 11 boundary agreements between 1991 and 1999 that included agreements and understandings on seven disputes ${ }^{27}$ (frontier disputes with India and Bhutan remained unresolved). The effort to resolve frontier disputes was an important aspect of Chinese foreign policy throughout 1990s, for external conflict in the wake of regime insecurity could weaken the state and hinder its domestic consolidation process. The continuity of frontier disputes meant direct or indirect rivalry with neighbours and lack of economic development - that depended on cross-border trade, industrialisation, and infrastructure development - in already less-developed, porous regions of the country. In other words, frontier disputes hindered Deng's 'four modernisations.' The resolution of frontier disputes was important for continuation of the modernisation and the consolidation process. The most important, and arguably the most powerful, among the disputants was the Soviet Union (now Russia).

The PRC leadership agreed to Mikhail Gorbachev's proposal of delimiting the eastern boundary on the basis of the thalweg principle. In 1989, the PRC dropped its demands for a comprehensive settlement and agreed to sign sector-specific deals. Beijing and Moscow produced an eastern sector agreement in 1991, while negotiations for other disputes continued even after the break-up of the Soviet Union. In 1993, a SinoRussian joint commission started the delimitation process that was completed in 1997 with approximately 1185 boundary markers. Agreement over the western sector, a 55-kilometer stretch after the Soviet dissolution, was reached in 1994, while the delimitation process in the sector was completed in $1997 .^{28}$

\footnotetext{
${ }^{26}$ M. Taylor Fravel, Strong Borders, Secure Nation: Cooperation and Conflict in China's Territorial Disputes (Princeton: Princeton University Press, 2008).

${ }^{27}$ Ibid., 126.

${ }^{28}$ Ibid., 138-144.
} 
Incrementalism, Normalisation, Partnership and Reassurance:

PRC's Quest for Success in the 1990s

Negotiations on frontier disputes with Laos and Vietnam progressed concurrently. Beijing's effort to delimit its border with Vientiane helped both sides normalise their bilateral relations. Formal negotiation with Vientiane started in August 1990. Experts from both sides reached a consensus in the first half of 1991 that led to the signing of a treaty in October 1991 during Premier Li's visit to Laos. Fravel adds that the 'treaty affirmed the boundary line derived from the original ChineseFrench treaties, and the 18-square-kilometer area under dispute was divided almost evenly between the two sides.' Delimitation process to survey the boundary and place boundary markers began in 1992. In 1993, the two sides signed a boundary protocol that included the location of 45 boundary marks dividing China and Laos. ${ }^{29}$

Delimitation with Russia and Laos might have proved straightforward, but the CCP leadership was aware of the challenges of boundary disputes with Vietnam because the list included South China Sea's (SCS) disputed islands. Any effort to normalise relations withthis long-estranged neighbour required consensus on an array of matters including island disputes, delimitation, and Cambodia - progress was expectedly slow.

Unlike the above cases, China and Vietnam began with 'quiet talks' in May 1990 (delimitation would follow normalisation). It took the two sides six years and 13 rounds of talks to begin an aerial survey of the boundary. The following three years elapsed before they were able to sign a boundary treaty in December 1999. ${ }^{30}$ Although progress on disputes with Hanoi remained slow, Beijing's key objective of normalisation was achieved by the mid-1990s.

Negotiations with Socialist states served the PRC on many fronts Talks with the Soviets, for instance, helped China delimit borders with the CARs. Chinese and Central Asian diplomats, in principle, agreed to continue from where Beijing and Moscow had left. ${ }^{31}$ Kazakhstan had most

\footnotetext{
${ }^{29}$ Ibid., 144-146.

${ }^{30}$ Ibid., 147-148.

${ }^{31}$ Beyond the frontier disputes and peaceful neighbourhood, an important reason for cooperation was the presence of Uighur population in Kazakhstan and Kyrgyzstan. Later, in the mid-1990s, China's multilateral approach, particularly through SCO, served
} 
Muhammad Shoaib, Ahmad Sabat \& Dr Saira Aquil

of the disputed sectors, comprising approximately 2240 square km; Xinjiang shared approximately 80 per cent of the total border. Beijing and Almaty reached an agreement in July 1993 that they initiated in 1994. Agreements on the remaining three disputed sectors were reached in 1997 and 1998. Similarly, Beijing worked with Bishkek to sign a delimitation agreement, covering approximately 3650 square $\mathrm{km}$ of the disputed territory. Both agreed to establish a joint delegation in the early 1990s that began the process of drafting a delimitation agreement circa mid-1995. In 1996, Presidents Jiang Zemin and Askar Akayev signed a border agreement covering six disputed sectors. The remaining dispute over Uzengi-Kush river basin was settled in August 1999. ${ }^{32}$

Although Tajikistan had inherited only three disputed sectors, a few of them, such as on the Pamir Mountains, were as ancient and involved a large tract of territory. Chinese and Tajik diplomats and experts continued to negotiate on disputed sectors throughout the early 1990s, but they were unable to reach an agreement until 1997. ${ }^{33}$ In October 1997, Vice Foreign Ministerial level talks between the two sides led to an agreement over smaller disputes. In 1999, Jiang Zemin and Emomali Rahmonov signed the delimitation agreement. China and Tajikistan reached an informal agreement in 2000 on Pamirs which Jiang and Rahmonov signed in May $2002 .^{34}$

\section{Hegemony, Challenge or Partnership: The PRC's US Policy}

Diplomacy via 'damage control' and, concurrently pursuing the resolution of frontier disputes - buttressing the normalisation process - helped China recover its post-6/4 image. But China, especially in the mid-1990s, needed more than that: Deng's 'four modernisation' plan had already shown signs of fruition. Already economic opening and trade with the

\footnotetext{
it in pursuit of energy resources, trade, anti-hegemony coalition, and combatting extremism and splitism.

${ }^{32}$ Ibid., 160-165.

33 Tajik civil war and the magnitude of the Pamir dispute were two major reasons. John Garver, "The Sino-Soviet Territorial Dispute in the Pamir Mountains Region," China Quarterly 85 (1981): 107-118, https://doi.org/10.1017/S0305741000028058.

34 Fravel, Strong Borders, Secure Nation, 164-166.
} 
Incrementalism, Normalisation, Partnership and Reassurance:

PRC's Quest for Success in the 1990s

developed world had helped China structure and integrate its economy into the global trade system. Against this backdrop, the US had been helpful throughout the 1980s, and supported China to grow as an economic market that attracted American businesses. CCP's key objective of economic development, underpinning its legitimacy, also required augmentation of the interdependence and continued support of the US in the guise of access to merchandise, capital, and public goods; China as a market attracted the US businesses. On balance, however, Beijing needed Washington more than the other way around. ${ }^{35}$

Immediately after 6/4, as stated above, Deng took the lead in dealing with the US (he would convey and receive messages through his old friends). ${ }^{36}$ As the situation normalised and Deng grew old, Jiang Zemin matured as his successor. ${ }^{37}$ Jiang knew the inherent complexities associated with the relationship, but he, like Deng before him, had the larger strategic picture in mind: US-China relations were important and larger than matters like a few hundred murdered students, human rights, and the US support of Taiwan. ${ }^{38} \mathrm{He}$, however, did not enjoy the same respect, loyalty, and influence in CCP and People's Liberation Army (PLA) as Deng did; he lacked Mao's personality and Deng's efficacy. $\mathrm{He}$ had to listen to both sides, PLA more in some cases, for he knew the importance of its continued support. It may be possible that emotion and fear, not Grand Strategy, drove Jiang's policy towards the US in cases like the Taiwan Strait crisis. Fluctuations in the US policy also existed military confrontation with the US in Taiwan Strait provides evidence.

\footnotetext{
${ }^{35}$ The centrality of the US as an economic and political power for China does not imply consensus among the Chinese leaders. Hardliners and moderates advocated contending policy courses. Hardliners emphasised strong response and tough internal control, moderates advocated Deng's low-profile approach until appropriate times. Ibid.

${ }^{36}$ Friendship between Deng and Bush went back to mid-1970s when the latter was stationed in China. Deng requested a private meeting with Bush during his 1979 visit to the US where he told him about his plan to attack Vietnam. He called Bush his friend in front of Brent Scowcroft and Lawrence Eagleburger. Vogel, Transformation of China, 649-650. After 6/4, Deng received Leonard Woodcock, Richard Nixon, Michael Oksenberg, and Henry Kissinger. He had personal rapport with all of them. Ibid., 653.

${ }^{37}$ Vogel calls Jiang an "excellent political manager". Ibid., 686.

${ }^{38}$ Ibid., 184-188.
} 
Yet Jiang recovered swiftly from the miscalculations and pressure underpinning the Twain Strait crisis (as discussed below). A Politburo meeting in April 1996 decided to end the confrontational course, and Jiang put Qian back in charge to mend relations with the US.

The MFA-led dialogue with the US resumed in May 1996. Qian and his American counterpart Warren Christopher discussed an array of topics in their meeting. The Chinese side agreed to some US demands, particularly regarding non-proliferation. It assured to set up an efficacious export control system (but demanded confidentiality). It also assured, at least in principle, cooperation on intellectual property rights. Growing understanding between the PRC and the US and its allies also brought in some relief for political prisoners and dissidents in the former. ${ }^{39}$ Above all, this quid pro quo showed that Qian's incrementalism was working, yet again.

The groundbreaking event, especially for the CCP and MFA, came in the guise of the October 1997 Summit between top leaders of China and the US. Jiang's carefully choreographed visit served both purposes: external and domestic. By visiting Hawaii and Virginia and holding his own throughout the visit, he was successful in partially rehabilitating China's post-6/4 (also, post-Taiwan Strait crisis) image. Emulating Deng, in an unprecedented visit, he sent back home a message that Americans considered China their co-equal. Although Clinton did not agree to his suggestion for a Fourth Communique, he had the larger strategic picture in mind - the Communique was probably not his core objective. Next year, in 1998, when he visited China, his approach was flexible; several US demands were accepted: a joint press conference was televised (Jiang was able to graciously host his US counterpart and calmly rebuff his ideas at the same time). Chinese pliability, nonetheless, was not without quid pro quo. The US President had to reiterate his 1995 pledge involving 'three noes' on Taiwan.

\footnotetext{
${ }^{39}$ The PRC took encouraging steps to address concerns on human rights in 1997. Robert Suettinger, Beyond Tiananmen: The Politics of U.S.-China Relations 1989-2000 (Washington, D.C.: Brookings Institution Press, 2003), 315-325.
} 
Incrementalism, Normalisation, Partnership and Reassurance:

PRC's Quest for Success in the 1990s

The fanfare and goodwill built after the two US-PRC Summits did not last long — working relations and understating underpinning stability in bilateral relations arguably, for China's response to events, such as the Falun Gong peaceful demonstration and bombing of its embassy, was measured. ${ }^{40}$ Many in Beijing, including the Ministry of State Security (MSS), considered the group's emergence a Central Intelligence Agency (CIA)'s strategy to split China. ${ }^{41}$ Conversely, bombing of the Chinese embassy in Belgrade, Federal Republic of Yugoslavia, by a US aircraft, stirred a wave of nationalist protests. As Andrew Nathan suggests, 'A number of Chinese leaders believed that the embassy bombing was deliberate.' ${ }^{42}$ Virtually all Politburo Standing Committee (PBSC) members, except for Zhu Rongji whose proposals for a US-China deal over Beijing's possible entry into the World Trade Organization (WTO) were turned by Clinton in April 1999, ruled out the possibility of an accident. Phone calls - from the highest level of leadership - letters, and statements to convey US apologies were ignored by the CCP leadership. Protestors, with consent and help of state authorities, surrounded US consulates and diplomatic buildings; they stormed and burned the residence of the US Consular in Chengdu, Sichuan.

The nationalist protests were, nonetheless, not allowed to emulate a cultural revolution-style campaign (measured response was a better response). An annual leadership meeting at Beidaihe concluded with a consensus on continuing China's current course of external policy emphasising peace, economic globalisation, and relaxation of tensions. An encouraging development in the following months was Clinton's acceptance of Zhu's (previously rejected) package deal.

\footnotetext{
${ }^{40}$ Falun Gong, a religious group that the CCP saw as organised as the party, would eventually face the crackdown.

${ }^{41}$ The Falun Gong mainly came from Hebei, Shandong, Beijing, Inner Mongolia, Liaoning, and Henan. Zong Hairen and Zhu Rongji, trans., "Handling the Falun Gong Case," Chinese Law and Government 35, no. 1 (2002): 53-72, https://doi.org/10.2753/CLG0009-4609350153; Ibid., 173; Nathan, The Tiananmen Papers.

${ }^{42}$ Andrew Nathan, "Guest Editor's Introduction," Chinese Law and Government 35, no. 1 (2002): 3-16, https://doi.org/10.2753/CLG0009-460935013.
} 
Muhammad Shoaib, Ahmad Sabat \& Dr Saira Aquil

\section{Insecurity, Fear and Pressure: The Taiwan Strait Crisis}

Regime insecurity, fear of anarchy, and the sense of vulnerability served China well. However, the 'damage control strategy' underscoring incrementalism and normalisation did not please all stakeholders. ${ }^{43}$ Hardliners often lobbied for a tougher, military-edged response to developments in the region, including the US arms sales to Taiwan. ${ }^{44}$ They got their chance in 1995, with the consent of Jiang who wanted to keep the PLA supportive, when the US issued a visa to President Lee Teng Hui despite assurances from the State Department. MFA was caught off guard and Jiang's 'capacity to bear pressure was nearing its breaking point. ${ }^{45}$ The PLA leadership lobbied for military demonstrations to intimidate Taiwan's electorate and to convey the intended message Taiwan is part of the Chinese motherland. They, as well as other hardliners, had probably assumed that a credible Chinese threat would not only move Taiwan away from declaring independence, but also influence the Taiwanese electorate to pursue a prudent strategy leading towards one country, two systems. ${ }^{46}$

Beijing, therefore, responded quickly after the US announced that it would issue a visa for Lee. A day after the announcement, the visits of Chinese delegations to the US were either cancelled or postponed. The PRC declined to receive a special emissary from the US for a brief on the visa issue. It did not approve the incoming US Ambassador James Sasser; and China's Ambassador to the US Li Daoyu was recalled 'to report on his work.' Chinese commentators, meanwhile, continued to reprise the past US transgressions and interpreted the policy shift towards Taiwan as an effort to encourage splitism. Anger, pressure, and misunderstanding ultimately led to the beginning of an (unexpected) eight-month series of PLA military demonstrations against Taiwan, involving naval and air

\footnotetext{
${ }^{43}$ Qian was the target of PLA criticism. Chen Yun criticised Jiang for his willingness to make deals with the West. Ibid., 609.

${ }^{44}$ US sold 150 F-16 aircrafts to Taiwan in 1992.

${ }^{45}$ Chan, review of Same Bed Different Dreams, 49-51.

${ }^{46}$ Robert Ross, "The 1995-96 Taiwan Strait Confrontation: Coercion, Credibility, and the Use of Force," International Security 25, no. 2 (2000): 89-90, doi.org/10.1162/016228800560462.
} 
Incrementalism, Normalisation, Partnership and Reassurance:

PRC's Quest for Success in the 1990s

exercises and missile tests. Beijing warned foreign ships and planes to avoid the area before the tests that were conducted not far from Taiwan's coast.

Prolonging of the Taiwan Strait crisis was largely measured, especially from the PRC side. A clear pattern of threat-and-talk (like fightand-talk in the Korean and Vietnam wars) emerged amid the crisis. Negotiations followed military demonstrations. The first high-level meeting between China and the US after the July (missile) tests occurred in Brunei in August 1995. Secretary Christopher, in his meeting with Qian, restated the US' long-standing China policy and delivered a (secret) letter for Jiang from Clinton. ${ }^{47}$ China announced the second set of tests in mid-August - this time larger than the July tests. Again, foreign forces and ships were warned before. And again, a round of negotiations followed military demonstrations.

In October, the two leaders met in New York where the US reiterated its position on Taiwan. This pledge partially satisfied Jiang who ordered Ambassador Li to return to Washington. However, reiterated pledges were not sufficient since a handful of policymakers in Beijing considered Clinton pliable. Beijing's military coercion, as they probably put it, was working, so there was no need to change the course. After the Jiang-Clinton meeting, the PRC announced another set of forward-leaning exercises in October.

The PLA conducted naval exercises in October 1995. Seniors Politburo and Central Military Commission (CMC) members observed the exercises. As earlier, a round of negotiations with the US followed. By November 1995, it was evident that Chinese exercise and tests had had an impact on Taiwanese politics. The crisis pattern began changing in March 1996 when the Clinton administration ordered the deployment of two aircraft carrier battle groups, Nimitz and Independence, and Aegis antimissile cruisers within a few hundred miles of Taiwan. Yet, Beijing showed no signs of backing down. The PLA announced another set of

${ }^{47}$ Clinton's letter encompassed three assurances: the US recognises the PRC as the sole government of China; the US recognises that there is only one China; and Taiwan is part of China. 
forward-leaning exercises in March. The US-PRC tensions, however, began to decrease after Taiwan's March 23 Presidential Elections. Immediately after the elections, both sides began to repair relations. As for China, the crisis had brought in several benefits, along with apparent, short-lived embarrassment. For instance, hawks and propagandists, especially in the PLA, advocating US unwillingness towards conflict with China proved wrong. Their assessments about the elections in Taiwan also proved to be wrong ${ }^{48}$ Unexpected, forceful American intervention constrained the decision-makers to listen to MFA warnings in the future. ${ }^{49}$

By April 1996, the US-PRC crisis was over. A campaign underpinned by anger, pressure, and miscalculation ended with signs of relief for moderates and economic liberals in China. But some neighbours had also observed the intimidation campaign $;{ }^{50}$ Beijing, too, realised this. The post-1996 PRC external policy, thus, encompassed another approach - reassurance, based on incrementalism and normalisation.

\section{The PRC's Post-Crisis Diplomacy}

China's show of force in the SCS and Taiwan Strait made it evident that its neighbours were worried about its future course. Jiang understood that wary neighbours were detrimental to long-term objectives: maintaining that the international context is helpful for domestic development and reduces the likelihood that the opponents, involving the US, may use their power to halt the country's international aspirations. ${ }^{51}$ Already concerns about China's behaviour were antagonising the Association of Southeast Asian Nations (ASEAN) states; they aroused Japan's fears about China's future role in Asia-Pacific. Also, the PRC was increasing its military

\footnotetext{
${ }^{48}$ PLA's attempt to intimidate the Taiwanese electorate backfired and Lee won with 54 per cent of the vote. DPP secured 30 per cent of the vote-intimidation pushed toward autonomy and split. Ross, "The 1995-96 Taiwan Strait Confrontation," 118-9.

${ }^{49}$ One of the most important developments, however, was MFA's enhanced influence. Garver, China's Quest, 631-632.

${ }^{50}$ Japan emphasised peaceful resolution of the Taiwan issue.

${ }^{51}$ Avery Goldstein, "The Diplomatic Face of China's Grand Strategy: A Rising Power's Emerging Choice," China Quarterly, no. 168 (2001): 835-64, doi.org/10.1017/S000944390100050X.
} 
Incrementalism, Normalisation, Partnership and Reassurance:

PRC's Quest for Success in the 1990s

capabilities (CCP and CMC leadership considered it a necessary step, but strengthening the military concerned regional states). Although it frequently called the concerns about its growing military prowess unfounded, its behaviour was causing anxiety among the East Asian states - the uncompromising stance over maritime disputes and fortification of Mischief Reef (1995) were unsettling. ${ }^{52}$ Many of these states had enhanced security cooperation with the US. ${ }^{53}$

The likelihood of a united front against China was unacceptable. Hence, it needed to reassure the neighbours of its peaceful intent. Goldstein argues that the post-6/4 adhocism of Chinese foreign policy mainly ended in 1996 - with MFA back in the lead. The consensus among party leaders provided a framework for the external policy that aimed at reassuring wary states. Beijing undertook two interrelated efforts, multilateralism and self-restraint, to assuage their concerns. ${ }^{54}$ It intended to reassure them with actions that it would be a responsible and cooperative neighbour. Instead of signing security agreements like the US, it made comprehensive efforts to form bilateral and multilateral partnerships. In principle, it preferred to work in multilateral settings to avoid the risk of isolation.

The first multilateral treaty the PRC signed with its neighbours was in Central Asia. In April 1996, it became a founding member of Shanghai Five. ${ }^{55}$ In August 1996, it signed another multilateral agreement, Comprehensive Nuclear-Test-Ban Treaty (CTBT).

The second effort, self-restraint, became evident during the Asian Financial Crisis. Although there are contending views on the rationale for the decision, suffice it to say that China did not devalue its currency (a step that sent a positive message to Asian neighbours). Beijing also precipitated its efforts to form partnerships across Asia and other regions. ${ }^{56}$ It considered them important, for they contributed to its effort to

\footnotetext{
${ }^{52}$ Emma Chanlett-Avery and Ian Rinehart, The U.S.-Japan Alliance, report (CRS Report No. RL33740, Washington, D.C.: Congressional Research Service, 2016).

${ }^{53}$ Goldstein, "The Diplomatic Face."

${ }^{54}$ Ibid., 842.

${ }^{55}$ Ibid.

${ }^{56}$ Beijing had different labels for relationships — Strategic Cooperative Partnership with
} 
cope with unipolarity and foster multipolarity. Partnerships were not only important because they attracted other states or helped China prevent a potential coalition against it; they also served the propaganda purpose directed at the US.

After all, growing economic interdependence with the US had not changed China's strategic calculation. Potential threat from the US topped Jiang's list of external security concerns: The US' decision to dispatch two aircraft Carrier Battle Groups to the East China Sea had proved him right. Propaganda (as well as contingency preparations) was important at a time when the US had begun to revise its Cold War security treaties, despite the absence of a peer competitor, with Japan and Australia. The revised agreement between the US and Australia irked China, but it was the US-Japan agreement in 1997 that concerned it the most. Adding to the trouble was Japan's Taiwan policy. ${ }^{57}$ Tokyo talked about a peaceful resolution of the Taiwan issue, but it stopped short of providing any explicit assurance to China about its position on the issue.

Nonetheless, the CCP leadership was aware of the benefit of considering the larger strategic picture: relations with the US and even Japan were too important to be overwhelmed by a single issue like Taiwan. The US' hegemony could be challenged alongside the efforts to develop strategic partnership with it, though both sides interpreted a constructive strategic partnership in different ways. China found such a partnership helpful in coping with the US' potential constraints on its ascent. The efforts of working towards the partnership, thus, continued despite accusations of military and corporate espionage by the US. Hardliners in Beijing, advocating explicit opposition to the US' hegemony and joining hands with Russia and the developing world, were also ignored.$^{58}$ As long as the US did not threaten China's vital interests, the former was important for domestic development, and keeping Lee from

Moscow, Long-term Comprehensive Partnership with Paris, Trustworthy Partnership with Berlin, Comprehensive Cooperative Partnership with London, and Friendly and Cooperative Partnership with Tokyo. Goldstein, "The Diplomatic Face," 854-857.

${ }^{57}$ Ibid.

${ }^{58}$ A similar option has been discussed, Michael Pillsbury, China Debates the Future Security Environment (Washington, D.C.: NDU Press, 2000). 
Incrementalism, Normalisation, Partnership and Reassurance:

PRC's Quest for Success in the 1990s

pursuing a splitting course in Taiwan.

China's relations with Japan also followed the above logic stability in bilateral relations was indispensable as well as helpful since relations with Japan had already begun facing challenges after 1992. Although Beijing's dependence on Tokyo had reduced after the early 1990s, it was still important for trade, technology transfer, and peace and stability in East Asia. Yet, Jiang's effort to pressure Japan amid its economic stagnation could not work; his visit to Japan in 1998 was a failure - a rarity in the post-crisis PRC diplomacy. However, the failure did not halt cooperation between the two sides. Premier Zhu's visit to Japan in 2000 tamped down the troubles that had spoiled Jiang's visit. ${ }^{59}$

\section{Conclusion}

The PRC in the 1990s withstood the fear of anarchy and pursued a strategy comprising of incrementalism, normalisation, and reassurance. However, rationality and prudence did not always dominate. Pressure, emotions, and fear at times deviated the PRC's actions, from the grand strategy, that contradicted the [apparently] rational course. Challenges to the regime, particularly internal ones, and subsequent insecurities constrained leadership choices. Disagreements at the highest levels and differences between civil and military leadership perceptions and interpretations of regional developments implied contending policy prescriptions.

The (contending) policy prescriptions were forceful in the absence of party elders. The success of CCP leadership, thus, required developing consensus, for it was essential to assuage rivalries and rifts within the Party. The Party, under Jiang's watch, was able to develop consensus on most occasions. The Chinese leadership, throughout the 1990s, agreed to follow Deng's low-profile approach; except for the Taiwan Strait crisis, it was able to continue working with the US and the West in general. ${ }^{60}$

\footnotetext{
${ }^{59}$ Michael Yahuda, Sino-Japanese Relations after the Cold War (New York: Routledge, 2014), 24-39.

${ }^{60}$ Even the Taiwan Strait crisis, as we know of it today, was measured.
} 
Response to the US bombing was measured. In this sense, virtually every crisis brought the PRC closer to the US, and the two sides were able to maintain working relations.

Working with the US and its allies meant rehabilitation of China's post-6/4 image and much-needed breathing space for the consolidation process. Jiang knew that powerful external enemies, such as the US and Japan, were detrimental to the CCP's rule. Only in the era of relative peace among great powers, was the resolution of frontier disputes with neighbours and improvement in relations with African, Latin American, and Middle Eastern nations, possible. It was all necessary but not possible without the low-profile foreign policy that the PRC pursued. That policy demanded restraint - Deng imparted the same. The US' interference in internal matters such as Taiwan was unacceptable, but war with the former and invasion of the latter were not practical options - showing restraint and working with both peacefully were. Both these strategic choices were important for the PRC's economic development that underpinned CCP's legitimacy. Efforts for legitimacy as well as the consolidation process indirectly influenced the Party's working style and external policy. Beijing's priorities — from objectives such as maintaining stability and defending rights — required an inclusive approach that enhanced its acceptance across the globe as a friend, ally, or partner.

Most of the above trends are evident in the PRC's Twenty-first Century external policy. Beijing has tried to assuage the fears of its neighbours, and contributed to their economic development with, comparatively, minimum political strings attached. Its financial institutions and infrastructure programmes are available for virtually all regional states. The BRI, involving more than 60 states and a trilliondollar fund, covers large parts of Asia, Africa, and Europe. And yet, the BRI does not come at the expense of global financial institutions and economic growth; it rather contributes to both. CCP's focus on maintaining legitimacy provides a strong rationale for this go-global strategy. At the strategic front, the PRC has largely avoided provoking weak neighbours - it rectified policies and continued negotiating during standoffs on maritime issues - or invading them for ideological and 
Incrementalism, Normalisation, Partnership and Reassurance:

PRC's Quest for Success in the 1990s

economic reasons.

Three decades after 6/4, it is evident that today's PRC is largely different from that of Deng. It has come very far. However, this would not have been possible without the foreign policy course that it pursued in the 1990s. 